INÖNÜ

SAVAŞLARI'NIN

100. YILI

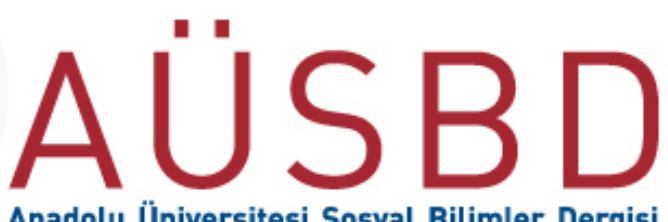

Anadolu Üniversitesi Sosyal Bilimler Dergisi Anadolu University Journal of Social Sciences

\title{
Ne Umdular Ne Buldular? Taraflar Açısından Birinci İnönü Savaşı ${ }^{1}$
}

\author{
Ercüment TOPUZ ${ }^{2}$
}

Başvuru Tarihi: 15.02.2021

Kabul Tarihi: 09.03.2021

Makale Türü: Araştırma Makalesi

\section{Öz}

I. İnönü Savaşı, istiklaline ve istikbaline yönelik tehditleri tenkil etme niyetine sahip olanlar ile tarihi bir arka plana istinat ettirdikleri ütopik tahayyüllerini İtilaf Kuvvetleri'nin yardımıyla gerçekleştirme sevdasına tutulmuşlar arasında meydana gelen bir muharebedir. Tarafların kendi iç çelişkilerini çözümlemeden savaşa iştirakleri (Yunanistan'in taarruzu keyfi, Millî Mücadele taraftarlarının müdafaası ise zaruridir) harbin nitelik olarak küçük ölçekli bir çarpışma olarak değerlendirilmesine neden olmuştur. Yunanistan'ın "Megali İdea" idealine ve İtilaf Kuvvetleri nezdindeki itibarına hizmet etmesi niyetiyle başlatmış olduğu taarruz, Millî Mücadele taraftarlarının mukavemeti ile karşılanmıştır. Taarruz taraftarlarının Atina ve Londra'da yaptıkları hesaplar İnönü sırtlarında hayal kırıklı̆̆ına uğratılırken harpten elde edilen hasılat Ankara'nın siyasi ve askeri çelişkilerinin çözümüne olanak sağlamıştır. Çalışma, meclis zabıt cerideleri, dönem neşriyatından ilgili gazeteler ve savaşta yer almış ve komuta merkezinde bulunmuş müşahitlerin hatıraları başta olmak üzere ikincil kaynaklar dikkat-ı nazara alınarak hazırlanmıştır. Harbin tarafı olan Yunanistan'ın durumuna ilişkin değerlendirmelerde ise mezkûr ülkede veya Avrupa'da neșredilen gazetelerin savașla ilgili bölümlerini tercüme ederek okurlarıyla paylaşan İstanbul neşriyatının paylaşımları dikkate alınmıştır.

Anahtar Kelimeler: I. İnönü Savaşı, Millî Mücadele, Megali İdea, Gazete, Propaganda

Atıf: Topuz, E. (2021). Ne umdular ne buldular? Taraflar açısından Birinci İnönü Savaşı. Anadolu Üniversitesi Sosyal Bilimler Dergisi, 21(Özel Say1), 43-58.

\footnotetext{
${ }^{1} \mathrm{Bu}$ çalışma etik kurul izin belgesi gerektirmemektedir.

${ }^{2}$ Van Yüzüncü Yll Üniversitesi Edebiyat Fakültesi Tarih Bölümü, ercumenttopuz@yyu.edu.tr, ORCID: 0000-0001-9458-1384
} 
İNÖNÜ

SAVAŞLARI'NIN

100. YILI

\title{
What Did They Hope, What Did They Find? The First Battle of Inönü From the Point of Parties Views
}

\author{
Ercüment TOPUZ ${ }^{3}$
}

Submitted by: 15.02 .2021

Accepted by: 09.03 .2021

Article Type: Research Article

\begin{abstract}
The first Battle of İnönü is a battle between those who intend to destroy the threats to their independence and future and those who strive to carry out their utopian dream of retaining a historical background with the help of the Entente forces. The parties' participation in the war without resolving their own internal contradictions (Greece's offensive is arbitrary, and the defense of supporters of the national struggle is necessary) caused the war to be considered as a small-scale collision in nature. The attack launched by Greece with the intention of serving the "Megali Idea" and its reputation with the Entente forces was met with strength by supporters of the national struggle. The accounts of the supporters of the attack in Athens and London were disappointed in Inönü's backs, while the proceeds of the war allowed Ankara to resolve its political and military contradictions. The study was prepared with taking into consideration of secondary sources, especially parliamentary police reports, relevant newspapers from the period, and memories of observations that took place in the war and were in the command center. In the assessment of the situation of Greece, which is a party of the war, the shares of Istanbul publications that translate the war-related sections of newspapers published in the country or Europe and share them with their readers were taken into account.
\end{abstract}

Keywords: First Battle of İnönü, National Struggle, Megali İdea, Newspaper, Propaganda

\footnotetext{
${ }^{3}$ Van Yüzüncü Yıl University Faculty of Literature Department of History, ercumenttopuz@yyu.edu.tr, ORCID: 0000-0001-9458-1384
} 


\section{Giriş}

XIX. yüzyılla birlikte, artık değerlerin paylaşılamamasından doğan sorunların çözümünde iki etken ön plana çıkarılmıştır. Bunlardan birisi konvansiyonel silahlar diğeri ise kitlesel haberleşme araçlarıdır. I. Dünya Savaşı her iki etkenin çok yoğun bir şekilde kullanıldığı uzun soluklu bir çarpışma ortamı olmuştur. Siyasi haritaların, iktisadi nüfuz sahalarına göre taksim ve tasnif edilmesinden kaynaklı olarak savaşın çok geniş bir sahaya yayılması, konvansiyonel silahların etkisini cephelerle sınırlandırırken kitlesel haberleşme araçlarının önemi artmıştır. Cepheyi maddi değerler ve manevi kıymetler ile finanse eden cephe gerisinin, konsolide edilmesinde veya yıpratılmasında kullanılan kamusal iletişim unsurlarının savaşanlar tarafından çok fazla önemsendiğine şahit olunmuştur.

Savaşa taraf olan Osmanlı Devleti’nde de aynı hassasiyet söz konusu olmuştur. Özellikle üç kıtaya uzanan sınırları ve farklı unsurlara ev sahipliği yapması, konvansiyonel silah gücünü minimalize edeceğine ve propaganda savaşının yoğun olarak yaşanacağına delalet etmiştir. Böyle bir zaafiyetin nasıl bir acziyete yol açacağının farkında olan devlet, cephe gerisinin düşman tezviratlarıyla yıpratılmamasını önlemek ve kendi gerçekliği üzerinden konsolide etmek amacıyla kitlesel haberleşme araçlarına ayrı bir ehemmiyet atfetmiştir. Savaşın uzaması, konvansiyonel silahların belirleyiciliğini azaltırken kitlesel haberleşme araçlarının önemini artırmıştır. Savaşın sonucuna, kitlesel haberleşme araçları üzerinden gerçekleştirilen propagandanın doğrudan doğruya etki yaptığını ifade etmek abartı olmayacaktır. I. Dünya Savaşı’nda kitlesel haberleşme araçlarının psikolojik bir savaş yönetimi olarak etkin bir şekilde kullanılması, 1917 yılında Avrupa başkentlerinde ortaya çıkan gösterilere yansımıştır. Berlin'in bu süreci iyi yönetemediği ve Londra'nın tezviratları karşısında Almanların yıprandığı ve bu durumun savaşın kaderine etki ettiği Fevzi Paşa tarafından dile getirilmiştir. "Bugün karşımızdaki İngilizlerin planları yıpratma harbidir, İngilizler Almanları da böyle yıprattılar ve bizi de öyle yıpratmak istiyorlar. İçimizde isyanlar çıkarmak; ufak, ufak taarruzlar yapmak ve daima muharebe, muharebe... Bu suretle bizi yıpratıp sükût ettirmek istiyorlar. Biz de bu plana karşı lâzım gelen tertibatı ittihaz edersek, o halde düşmanın bu planını suya düşürmüş oluruz (TBMM.ZC., 9 Kanun-1 Evvel 1336, s. 253).

Fevzi Çakmak Paşa'nın "tezvirata dayalı yıpratma savaşı” olarak tesmiye ettiği mücahedenin en önemli enstrümanının kitlesel haberleşme araçları olduğunu vaz’ etmek, izahtan varestedir. Paşa mezkûr tespitiyle yokluklar içerisinde vücut bulmaya çalışan Millî Mücadele hareketinin muvaffakiyetini bu tür tezviratlara kanmamakla, birlik ve beraberliğin muhafazasına koşullandırılmış neşriyatla ve fikirdaşlıkla mümkün olacağı tespitinde bulunmuştur. Büyük Millet Meclisi'nde dile getirilen bu ifadelerin nasıl bir gerçeklik küresine tekabül ettiği ise; I. İnönü Savaşı’nı takip eden gazete sayfalarında gözlemlenmiştir.

Millî Mücadele’nin cidal kısmı sahada sürdürülürken cedel bölümü de masada eda edilmiştir. Hem askeri hem de siyasi kavgaların muhatap kitlesi, kalem vasıtasıyla muayyen bir hedefe kanalize edilerek, belirlenmiş bir ülkü üzerinden konsolide edilmeye çalışılmıştır. Bu bağlamda başta Millî Hâkimiyet gazetesi olmak üzere çeşitli ulusal ve yerel gazeteler neşredilmiş, broşürler, afişler, risaleler basılmış, Anadolu Ajansı kurulmuş ve edebi, dini çevrelerin ifade kabiliyetleri camilerde sokaklarda caddelerde ve cephelerde etkin bir şekilde kullanılmıştır. Bu çaba sadece kendi iç kamuoyuna yönelik olmamış I. İnönü Savaşı’nın hemen öncesinde Ankara'da bir Fransızca gazete çıkarılarak Avrupa'nın iç dinamiklerine de hitap edilmeye çalışılmıştır.

Millî Mücadele esnasında cephede olduğu gibi cephe gerisinde de hitabet ve kitabet üzerinden kavgaya iştirak, özellikle Yunanistan'ın militarist hareketlerle yayılmacı politikasını meşrulaştırmak için tezvirata dayalı propagandalarına cevap vermek kaygısından ileri gelmiştir. Yunanistan, Anadolu'nun taksimini firsat bilerek ütopik tahayyülüne tesmiye "Megali İdea" arzusunu gerçekleştirmek için başta nüfus olmak üzere çeşitli tarihi tezviratlarını, ameli ve nazari planda Avrupa kamuoyunda pratiğe etmiştir. Bu plan ve programını askeri faaliyetlerle pekiştirmek için Anadolu'ya asker çıkarmış (siyasi antlaşmalara rağmen) ancak I. İnönü Savaşı'nda 
olduğu üzere başarısızlığa uğramıştır. Tarihi tezviratlarına payanda işgal niyetinin hayal kırıklarını da kitle iletişim araçlarıyla örtmeye çalışmış, Millî Mücadele’nin sözcüsü ile birlikte suya ve sabuna dokunma konusunda tereddütleri olan İstanbul neşriyatı bu durumu ifşa etmiştir.

Yunanistan'a, ütopik tahayyülü üzerine Atina'da yapmış olduğu hesapların, hakikatten ne kadar uzak olduğunu gösterecek ilk mesaj 9-11 Ocak 1921'de İnönü mevkiinde verilmiştir. Mezkûr mesajı “evdeki hesap çarşıya uymaz" darb-1 meseliyle kendisine hatırlatan İsmet (İnönü) ve komutası altındaki ordu mensupları olurken bu gerçeği afişe edip dâhili ve harici dünyaya servis etme mükellefiyetini ise dönem neşriyatı üstlenmiştir.

\section{İnönü Savaşları Öncesinde Büyük Millet Meclisi}

I. Dünya Savaşı, insani insiyakların tarihi tecrübe ile terbiye edilebileceği iddiasının bir safsatadan ibaret olduğunu göstermiştir. Son bir gayretle zikredilen iddianın tutarlı bir teklifi olarak Wilson İlkeleri ön plana çıkarıldığı zaman, özellikle savaşın mağlupları açısından bir ümit kaynağı olmuştur. Ancak Sevr Antlaşması (10 Ağustos 1920) bu beklentinin boş bir tahayyül olduğunu ifşa etmiştir. Sürecin önderliğini deruhte eden İngiltere’nin sömürgeci iştahını tatmin, mevcut sömürgelerine yönelik tehditleri tahdit etmek maksadına matuf siyasi ajandasının sembolü olan Sevr Antlaşması ${ }^{4}$, fiilen ortadan kaldırılmış olan Osmanlı Devleti’nin hukuken de sonuna işaret etmiştir.

Altı asırlık bir devletin sonuna işaret eden bu gelişme, yeni bir dirilişin hesaplarını yapan M. Kemal (Atatürk) ve arkadaşları için pek büyük bir sorun olarak görülmeyebilirdi. Ancak devlet denen şahsi manevinin şahsiyetine taalluk eden milletin istiklalinin ferdi selamete indirgenmesi ve şahsiyeti şahıslaştıran mütefekkirlerin de istikbali mandaterlik üzerinden örgütlemesi, mezkûr cephe açısından büyük bir sorun olmuştur. Millî Mücadele'nin müessis kadrosu, tarihi tecrübeye dikkat ederek millet olmanın bilincini tekrar diriltmek ve milli bir düşün ve düşünce adamını yeniden uyandırmak üzere bir metot geliştirmişlerdir. Bunları böyle bir tercihe sürükleyen tarihi ibret vakası ise F. Rıfkı Atay’n, Yahya Kemal Beyatlı'dan iktibasla dillendirdiği tarihi tespittir. Bahse konu tercih Atay tarafından şu şekilde tasvir edilmiştir. "Tanzimatçılar bir millet değil, bir vatan yapmağa çalıştılar. Tarih gösteriyor ki eğer millet kalırsa, kaybolan vatanı yerine koymak imkânı vardır. Biz parçalanırsak, elden ele geçersek millet olarak kalabilir miyiz? Devletin çekildiği yerlerde Türklüğün tükendiğini görmüyor muyuz? Fes Köstence'de hamalın, Filibe istasyonunda pabuç boyacısının başında kalmış...” (Atay, 1980, s. 130).

Millî Mücadele'nin müessis kadrosunu teşkil eden başta M. Kemal (Atatürk) olmak üzere diğer askeri ve siyasi kanatın ilk önceliği, millet bilincinin tekrardan ihya etmek olmuştur. Tanzimat'ın, imparatorluğu kurtarmak adına öne sürdüğü politik toplumsal tasavvurların neden olduğu kimlik kargaşasılyla birlikte I. Dünya Savaşı'nın getirmiş olduğu maddi ve manevi yıkım, kurutuluşu kendi köy ve toprağıyla bir tutan bir anlayışın toplum nezdinde yerleşmesine neden olmuştur. Milliyetçi anlayışı rahatsız eden bu tespitin en önemli argümanlarından birisi, I. Dünya Savaşı esnasında hareket şube müdürü olarak görev yapan İsmet İnönü’nün askeri firarlara ilişkin paylaştığı 300.000 rakamıdır (İnönü, 2009, s.123). Bu vazgeçmişliğin tasvirini ise Falih Rıfkı Atay “Çankaya” isimli eserinde müşahitlerin nazarından yapar. Kırklareli’den M. Kemal' e gelen raporda

\footnotetext{
${ }^{4}$ Sevr Antlaşması'nın İngiltere tarafından bir siyasal ajanda olarak kullanılmasının temel saiklerinden biri sömürgeleştirdiği ve isim babalığını yaptığı "Orta Doğu” nun, İstanbul merkezli Anadolu teslim olmadan idare edemeyeceği gerçeğidir. Dönem neşriyatı da bu niyeti farklı bir ifade biçimiyle ilgililerin istifadesine sunmuştur. 12 Kanun-1 Sani 1921 tarihli İkdam gazetesinin haber-yorumunda “İngiltere’nin Sevr Muahedesi'nin tasdiği, Yunanistan'ın takip edeceği hatt-ı harekete bağlıdır." tespiti yapılmış ve ilerleyen günlerde bu haber daha ayrıntılı bir içerikle okurlarıyla paylaşılmıştır. 14 Kanun-1 Sani 1921 tarihli bir diğer haber-yorum ise şu şekildedir; “Britanya hükümeti Sevr Muahedesi’ni tasdik etmemiş ise bile, İngiliz parlamentosunun müzakere ideceği başka mevad mevcud olmasından münbaisdir. Fakat vekayi’i ahireden sonra İngiltere hükümeti muahedeyi tasdik etmeden evvel Yunanistan ve Şark kurbundaki vaziyetin daha ziyade tavzih etmesine intizar eyleyecektir.” (İkdam, 14 Kanun-1 Sani 1921;1)
} 
insanların fakr u zaruret nedeniyle silahlarını Rumlara sattığı, Fransızlara karşı mücadele veren Kuvâcı Hamdi Bey'in halkı çetelere haraç vermek yerine cepheye para ve gönüllü göndermesi için yaptığı baskı nedeniyle halk tarafından işkenceye maruz bırakılarak öldürülmesi, Albay Bekir Sami Bey’in Akhisar' a ilişkin burada kimsenin asker olmak istemediği, jandarma bölüğünden kaçan kaçana olduğu, Bandırma'dan Balıkesir'e bütün istasyonlarda Yunan Bayrağı çekildiği, mallarının ve canlarının Yunanlılarla emniyet altına alınacağı inancı ve ezcümle "Biz bir şey yapamayız. Devlet asker gönderirse gönderir. Yunanlıya boyun eğeriz." (Atay, 1980, s. 238-239) söylem ve yaklaşımları I. İnönü Savaşı öncesinin genel bir resmidir. Böyle bir tablo Trablusgarp ile başlayan, Balkan savaşlarıyla devam eden ve I. Dünya Savaşı'yla neticelenen bozgunun ortaya çıkarttığı maddi ve manevi yıkımdan kaynaklanmıştır. Bir asırlık tarihi hüznün üç yıla sığdırılmasından doğan hasılat (Veysi, 1340, s. 1), Anadolu insanı nazarında vatan hissiyatını; mensubu olduğu dinin, dilin, kültürün ve tarihin şahsi manevisi olarak değil de kendi varlığıyla ve toprağıyla eş tutacak bir bilince indirgemiştir. Kısa bir süre zarfında bu indirgemeci tavrı telafi edip Büyük Millet Meclisi nezdinde Anadolu'yu tekrardan mücadelenin tarafı haline getirmek, zikrolunan tatbikatın başarısı hakkında bilgi vermektedir.

M. Kemal (Atatürk) ve arkadaşlarının ikinci önceliği istikbalin, zamanın ve mekânın inisiyatifini elinde bulunduranların terbiyesine sığınarak kurulmasını teklif eden siyasi ve fikrin müdafileri olan mütefekkirleri milli bir çizgiye çekmek olmuştur. Çarlık Rusya'nın 1917 Ekim Devrimi'yle iktidarı ele geçiren Bolşeviklerin gizli antlaşmaları ifşa etmesi, Osmanlı siyasi çevrelerinde bir infiale yol açmıştır. Milletinin istiklaline ilişkin bu telaşenin teskin ve tenkili ise ehven-i şer olarak birçok mahfilde dillendiren mandaterliği gündeme getirmiştir (Atay, 1980, s. 141-142). Böyle bir teklifin muhataplarından olan Celal Nuri (İleri)'nin bu durumu tenkit düzeyinde tasvir etmesi çok ilginç bir politik ikiyüzlülük ortaya çıarmıştır. "İmtisalen meydana konan en son fikir bir hayli taraftar buluyor. Amerika mandası bu kabildendir. Halbuki haysiyetini müdrik hiçbir millet, velayet altına alınmayı istemez. Bizim son dereceye kadar dava ettiğimiz ve ideceğimiz istiklalimizdir. Nitekim Avrupa matbuatında görüldüğü üzere Türkiye’nin mukasemesinden ise ....(Nuri, 1335, s. 1)” ölümü göze olan C. Nuri İleri'nin bu değişimi Anadolu'da ortaya konan mücadeleye duyulan inançtan doğmuştur.

Müktesebatını gayri medeni telakki edip kuvvet ve iktidar sahiplerinin kudretine vasıl olmak için belli bir süre mezkûr muktedirleri mürebbi olarak tanımanın adı olan mandaterliğin; milletin gayret ve cesaretine duyulan güvensizlikten ileri geldiği ise izahtan varestedir. Mersin Mebusu İsmail Sefa Bey’in mecliste "Bütün Avrupa, hatta kendimiz içimizden milletimizin kabiliyetsiz olduğunu iddia ediyor idik ve böyle bir zan kafalarımıza yerleşmişti” (TBMM. GZC., 17 Mart 1337, s. 6) nutkundan da anlaşılacağı üzere mandaterliği meşrulaştıracak bir bilinçaltının belli çevrelerde hakim olduğu görülmektedir. Ancak ittihatçı zihniyetin cesaretiyle ortaya çıkan kuvâcı kudreti belli bir hedefe kanalize ederek mücadeleye yeni bir boyut kazandıran Mustafa Kemal (Atatürk) teslimiyeti tel'in ve istiklali teklif ederek komuta merkezini konsolide etmeyi başarmıştır. Mustafa Kemal (Atatürk) ve düşüncelerine paydaş olan komuta tabakasının masadaki mücahedeleriyle sahadaki mücadelelerine duyulan güven, milli hissiyatın ihyasına kapı aralamıştır. Mustafa Kemal (Atatürk) ve silah arkadaşlarının önderliğinde milletin istiklaliyet noktasında ortaya koyduğu azim ve kararlılık karşısında "milletimiz herkesin dimağına yerleşmiş yanlış bir zihniyeti iflas ettirdi. Hâlbuki büyük ve necip milletimiz hiçbir millete nasip olmayan bir kudret ve kabiliyet gösterdi.” (TBMM. GZC., 17 Mart 1337, s. 7). sözleri mandaterliğe ilişkin temayüllerin tenkiline tam bağımsız bir düşüncesin daha yüksek bir perdeden seslendirilmesine sebep olduğu gibi İngiltere'nin nezdinde Yunanistan'ın İstanbul merkezli Anadolu tasavvuratının ütopik bir tahayyül olarak ertelenmesine de neden olmuştur.

İstiklal ve istikbale yatırım yapan bu çabanın meşruiyet çizgisini İngiltere’nin, halifeliğin ve sultanlığın sadrını teşkil eden payitaht İstanbul'u işgal etmesi oluşturmuştur. İstanbul'un işgali sonrasında M. Kemal (Atatürk), Osmanlı egemenliğinin sona erdiğini ifade ederek Heyet-i Temsiliye’nin ülke yönetimine el koyduğunu kamuoyuna duyurmuş (Küçük, 2009, s. 3), bu gelişme, kamuoyunu Millî Mücadele lehine konsolide ederken 
İngiltere’nin siyasi hesaplarla oluşturduğu haritaları da alt üst etmiştir. İngiltere önderliğindeki İtilaf Devletleri böyle bir direnişi, siyasi telkinlerini tahfif ve askeri tehditlerini tahkim ederek tenkil etmeye çalışmıştır (İradei Millîye, 1 Mart 1336, s. 1). Sultan ve Halife'nin halk üzerinde var sayılan otoritesinden istifade ederek direnişin direncini kırabileceği beklentisinin Anadolu'da çokta karşılık bulmaması üzerine, jandarma görevini tevdi ettikleri Yunanistan'ı sahaya sürerek tenkil ve te'dip siyasetini ön plana çıarmışlardır. Her iki siyaset, Anadolu direnişini ortadan kaldırmak yerine kongrelerde alınan kararların kamusallaştırmasına dolayısıyla milli hâkimiyet ve egemenlik tekliflerinin tecessümüne, terkibine ve yerel direnişlerin milli bir mücadele hüviyetine dönüşmesine neden olmuşlardır. Böyle bir zemin, Mustafa Kemal (Atatürk) ve arkadaşlarının aksiyoner eylemlerini yeni bir siyasi hedef ile (Türkiye Cumhuriyeti) reaksiyoner bir seviyeye taşıarak Türkiye Cumhuriyeti’nin temel taşları olan İnönü savaşlarının kapısını aralamıştır (Hilal, 23 Nisan 1922, s. 1).

İşgal dolayısıyla siyasi nizamını, askeri intizam üzerine tanzim eden Büyük Millet Meclisi'nin, I. İnönü Savaş1 öncesinde yaşadığı en büyük sorun, Batı Cephesi’nde Yunan ilerleyişi karşısında set olma gayreti içindeki Çerkez Ethem Kuvvetleri'nin zikredilen düzene karşı gösterdikleri direnç olmuştur (Atatürk, 2015, s. 385-397; Cebesoy, 2019, s. 517-519). Çerkez'in bu serkeşliği hem yeni düzenin millet nezdindeki meşruiyetini sorgulatmış hem de işgalci Yunan birliklerinin ilerleyişi için bir firsat oluşturmuştur. Bu olumsuz tablo Millî Mücadele’nin neşriyatı tarafından şu şekilde dile getirilmiştir. "Birinci Kuvve-i Seyyare Kumandanı Ethem Bey'in Büyük Millet Meclisi Hükümeti'nin hod be-hod iane ve asker toplanmaması hakkındaki evamir ve mukarreratını menafi'-i şahsiyesine mugayir görerek isyan etmesi akabinde kardeşleriyle birlikte düşman ordusuna (Yunan Kuvvetlerine) iltihak etmesi henüz kurulmuş yeni bir siyasi ve askeri birlik için bir zaafiyet oluşturduğu muhakkaktır (Hâkimiyet-i Millîye, 8 Kanun-1 Sani, 1337).”

Çerkez Ethem'in bu tercihi, siyasi nizamını askeri intizam üzerine kurmuş olan Büyük Millet Meclisi'nde psikolojik bir sarsıntı meydana getirmiştir. Aynı gün Meclis'te bütçe ile ilgili toplantıda dile getirilen iktisadi veriler ise mezkûr nizam ve intizamın nasıl bir zemin üzerinden beslendiğini göstermektedir. "Bizim umum memleketlerimizde, İstanbul, Edirne, Van, Adana, İzmir, Bursa dahil olduğu halde, ağnamımız 18 milyon kadardı. Üç milyon tiftik, on milyon koyun, beş milyon da keçi. Şimdi ise ağnamımız 12 milyon kaldı. Efendiler 15 milyon ahalimiz var. Nüfus başına bir koyunumuz bile yoktur. Olanları da biz bitirmekteyiz. Efendiler; köylü 1334 senesinde 35 kuruşa aldığı buğdayı 1335'te 15 kuruşa sattı. Geçen sene 15 kuruşa buğday aldı, bu sene beş kuruşa satıyor. Halbuki bu sene tahkik ettirdik mahsul bire dört ve beşten fazla olmamıştır. Bu sene umum rençber bi-tamamiha kesesinden yemiştir, kesesinden zarar etmiştir. Rica ederim, hiç olmazsa altlarına bir yatak, üstlerine bir yorgan, baş altlarına bir yastık; yazın güneşte, kışın karlarda kendilerine bir kepenek bari koyalım. Millet bitmiştir.” (TBMM. GZC., 8 Kanun-1 Sani 1337, s. 316).

Anadolu'nun, istiklal ve istikbal kaygıları üzerinden nizama ve intizama koşullandırılmış olmasının bir çıtısı olarak dillendirilen "millet bitmiştir" nidası "içtimai insafın" hudutlarına atıf yaparken bu insafın haysiyetine ilişkin durum tespiti ise dönem müşahit ve muhataplarından Yakup Kadri Karaosmanoğlu tarafından tasvir edilmiştir. Karaosmanoğlu, bahse konu nutuktan yaklaşık bir yıl önce "iyimser olmanın faydası" adlı yazısında bu bitmişliği, yeni bir hikâye yazmanın başlangıcı olarak tanımlamıştır. "Siyasi mukadderatımızın bu trajik safhasında toplar, tüfekler, seller, istilalar, zulümler, sefaletler önünde sönmek bilmeyen, hatta gittikçe artan nikbet ve afetlere rağmen gittikçe canlanan bu sşık, her halde ne bir yangının aksi ne de geceleri mezarlıklardan yayılan fosfor pırıltılarıdır. Mutlak içimizde bir şafak doğuyor, bu şafak milli şuurumuzdur. Gerçi, biz bu şuuru birçok gözyaşı ve birçok kan selleri içinden, birçok acılar ve istıraplar ile kıvrana kıvrana bulduk, fakat yeryüzünde hangi tepeye zahmetsiz varılır? Hangi doğuş kansız, gözyaşsız ve ihtilaçsızdır? Tarihin bütün şanlı devirleri, milletin bütün muazzam hareketleri hep böyle başlamadı mı? Her yeni âlem bir eski kıyametin mahsulü değil midir?” (Karaosmanoğlu, 1973, s. 22-24). 
I. İnönü Savaşı öncesinde Çerkez Ethem'in serkeşliği nedeniyle siyasi ve askeri alanda yaşanan zaafiyet diğer taraftan iktisadi bağlamda savaş ekonomisinin meydana getirdiği tükenmişlik, bir kıyamet alameti değil yeni bir kıyamın ve kıyamın emareleri olarak görülmüştür. Böyle bir görünüm M. Kemal’in (Atatürk) 1917 yılında kaleme aldığı raporun bir öngörüsüyle oluşturulmuş gibidir (Atay, 1980, s. 95-96). "Bizim için menba’1 kuvvet millettir” diyen M. Kemal (Atatürk) siyasi nizamı, iktisadi mizanı ve askeri intizamı, ihtiyaçlardan ziyade istiklal ve istikbal hassasiyetleri üzerine istinat ettirerek, Büyük Millet Meclisi'nin mezkûr sahalarda yaşamış olduğu sıkıntıları mücadelesinde birer engel değil mukadderatına bir motivasyon aracı yapmıştır.

İstikbale koşullandırılmış milletin azim ve kararlı̆̆ı, istiklalin istinatgâhı olduğu gibi aynı zamanda kudretine ve kutsiyetine iman ettiği saltanatlığı ve halifeliği öteleyecek müstakil bir siyasi sistemin ihdasına da imkân tanımıştır. Mersin mebusu İsmail Safa Bey'in Meclis-i Mebusundaki konuşmalarından mezkûr imkânı tasvir etmek mümkündür. "Bütün müesseselerimiz İstanbul'da iken, bütün yetişmiş adamlarımız orada iken ve orası düşman istilâsı altına düştüğü halde, hiçbir şey yok zannedilen Anadolu kendi kendine hatta İstanbul'un düşmanlığına rağmen İstanbul bütün müessesatıyla, asırlık zihniyetiyle ve bütün manasıyla aleyhimizde çalıştığı halde burada kudretli bir devlet teşekkül etti." Mücadelenin amirlerine memur olarak hem istiklalin hem de istikbalin istinatgâhı olan milletin bu başarıları kendisinin yüksek kudretinin eserleri olduğu ve bu tablo karşısında "canımızı almak isteyen milletler bizim gösterdiğimiz bu harikulade cesaret karşısında hayret ettiler.” (TBMM. ZC., 17 Mart 1337, s. 7). Böyle bir hayrete neden olan mümkünat, uzun vadede asırlık siyasi teamüllerin tasfiyesinde ve bazı alışkanlıkların da tasaffisinde, başta M. Kemal'in (Atatürk) olmak üzere dönem cumhuriyet kadrolarının işini kolaylaştırmıştır.

\section{I. İnönü Savaşı Öncesi Yunanistan'ın Durumu}

I. Dünya Savaşı'nın kazananlar safında yer alan Yunanistan, her ne kadar cephelerde pek arz-1 endam etmemiş olsa da (Temmuz 1917'de savaşa iştirak etmiş) Kral Konstantin ve Venizelos arasında yaşanan siyasi mücadelenin maliyeti ülkeyi siyasi, iktisadi, askeri ve toplumsal alanlarda uzun soluklu krizlerle yüzleşmek zorunda bırakmıştır. Balkan Savaşlarını başlatarak Yunanistan'ı karada ve denizde iki katına çıkartan ve elde ettiği başarılar ile "Megali İdea"”nın muhyisi unvanıyla şöhret olan Venizelos, bu mücadelenin muzaffer politikacısı olarak mezkûr maliyeti, zikrolunan savaşta olduğu gibi teşrih masasına yatırılmış Osmanlı Devleti'nden elde edeceği topraklarla telafi etmeye çalışmıştır (Çetin, 2018, s. 169-200).

$\mathrm{Bu}$ çabanın siyasi ve askeri çeperini ise Osmanlı Devleti'ne dikte edilen Mondros Ateşkes antlaşması sağlamıştır. Siyaseten işgalin meşru zeminini hazırlamış bu ateşkes, Anadolu’yu yangın yerine dönüştürecek bir baruthane olarak tasnif ve taksim etmiştir. Batı Anadolu sınıfının jandarmalığı ise kitle iletişim araçlarını etkin bir şekilde kullanarak "hayali Rum nüfus çoğunluğu” propagandası üzerinden Avrupa'yı etkileyen Venizelos nezdinde Yunanistan'a tevdi edilmiştir (Erdem, 2009, s. 114-133). İngiltere'nin Akdeniz'deki varlığını tahkim etmesine hizmet edecek gayri-resmi bu stratejik atama, İtilaf Kuvvetleri arasında bölünmeyi belirginleştirirken Yunanistan'ın tarihi emelleri noktasında bir fırsat ortaya çıkarmıştır. Kısa bir süre içinde İzmir ve çevresi, Yunanistan tarafından işgal edildiğinde Venizelos'un "Yunan Birlikleri'nin İzmir ve yöresini de facto işgali sırf mevcut şartlar dolayısıyla kararlaştırılmıştır ve gelecek için yeni bir hak yaratmamaktadır. $\mathrm{Bu}$, Paris Konferansı'nın Doğu Sorunu'nun yarattığı çeşitli problemleri çözme yetkisini, hiçbir şekilde kısıtlamayan geçici bir tedbirden ibarettir” (Sağlamer, 1971, s. 10) açıklaması ne mağdur Osmanlı Devleti tarafından ne de müttefikleri Fransa, İtalya ve ABD nezdinde makul bir gerekçe olarak algılanmamıştır.

Venizelos şahsında Yunanistan'ın Megali İdea tahayyülüne ve Loyd George nezdinde İngiltere'nin Şark tasavvuruna matuf bu tür taarruzlar, İstanbul'u teslimiyetçi politik tartışmalara sevk ederken Anadolu'da yeni bir mücadelenin meşalesini alevlendirmiştir. M. Kemal (Atatürk) gayretinde temsil edilen bu mücadele, Lloyd 
George'un tasavvurunu tebdil ve Venizelos'un tahayyülünü ise tenkil ederek Avrupa'da yeni tartışmaların kapısını aralamıștır. Bahse konu aralıkta Venizelos'un politikaları hem Avrupa'da hem de kendi ülkesinde sorgulanacak ve her iki dünyada kısa bir süre de olsa gözden düşecek ve 1921 seçimlerinde iktidardan uzaklaştırılacaktır. Bu vaziyet İstanbul'da neşredilen gazetede şu şekilde tavzih edilmiştir. "Yunanistan'da Venizelos'un sükûtu intaç eden mebussan intihabı ile Kral Konstantin'i Atina'ya davet eden rey-i umumiye üzerine Avrupa'da büyük bir cereyan-1 efkâr başlamıştı. Bu cereyana bi-t-tabi iştirak eden Düvel-i İtilafiye ricali siyasiyesi şarkta Yunanistan buhranından mütevellit hal ve vaziyet ile Türkiye sulhu telif edebilmek için Sevr muahedenamesi ahkâmını tadil etmek lazım geleceğini alenen ve resmen beyan eylemişlerdir." (Vatan, 9 Kanun-1 Sani 1921, s. 1).

Mondros Mütarekesi sonrasında Venizelos'un Megali İdea macerasının Anadolu'nun sinesinde muallakta kalması, İtalya, $\mathrm{ABD}$ ve Fransa nezdinde Yunanistan'ın dolayısıyla İngiltere'nin siyasal ajandasının sorgulanmasına ve iç kamuoyunda ise Konstantin taraftarlarının daha yüksek perdeden muhalefet etmelerine sebep olmuştur. Yunanistan, Venizelos'la yaşadığı bu başarısızlığı telafi etmek için yeni arayış içine girmiştir. Başta İngiltere'nin takdirine ve İtilaf Kuvvetleri'nin teveccühüne nail olmak için liberal politikalar uygulayacak bir kabine revizyonuna gitmiştir. Ancak bu sürecin sancıları Atina'da siyasi cinayetlerle gölgelenmiştir (Vakit, 9 Kanun-1 Sani 1921, s. 1).

Yunanistan'ın Anadolu'daki macerasının maliyeti, siyasi krizlerle sınırlanmamıştır. Londra merkezli gazete haberine göre "Yunanistan'ın büyük müşkülat-ı maliye ile mücadele halinde bulunduğu, bütçesinde yaşanan açılar nedeniyle muvazeneyi te'min idemiyeceği” haber-yorumu, mezkûr tespitin bir temsilidir (Vakit, 10 Kanun-1 Sani 1921, s. 2). Bu ekonomik buhranın ne denli derin olduğu 14 Ocaklı İkdam gazetesinde dile getirilmiştir. Yunan ve Avrupalı gazetelerden iktibasla yapılan haberde "Yunanistan'ın ekonomik bir darboğazdan geçtiği ve Amerika'nın kendilerine borç vereceği iddiasıyla yeni kurulan kabinenin istifa noktasına geldiği ifade edilmiştir (İkdam, 14 Kanun-1 Sani 1921, s. 1).

Askeri, siyasi, iktisadi ve içtimai açmazlarla boğuşan Yunanistan'ın Anadolu'da ki faaliyetlerini nasıl sürdürebildiğini sorgulamak gerekir. Kuruluşundan itibaren varlığını Avrupa'nın istimdadına istinat ettiren Yunanistan, insanlığın en buhranlı günlerinde de tarihi emellerine (Megali idea) ulaşmak için aynı niyetle hareket etmişlerdir. Kendi potansiyelleri ile paralellik arz etmeyen tarihi plan ve programlarında Avrupa'nın yardımını sağlamak için propaganda faaliyetlerine hız kazandırmışlardır (Erdem, 2009, s. 115). Bu hareketlerini iki adımda gerçekleştirmiştir. Birincisi, I. Dünya Savaşı’nın son düzlügünde İtilaf Kuvvetleri tarafında yer alarak geç kalma psikolojisini propaganda faaliyetleriyle bertaraf ederek pastadan pay almak noktasında meydan-ı harpte "bende vardım", ikincisini ise Megali İdea'nın mekânı Anadolu'yu parsellemek için öne sürdügü nüfusa ilişkin tezviratlarında "ben ordaydım" şeklinde formüle edilebilecek iddialarıdır. "Bende vardım”, "ben ordaydım” propagandalarının Avrupa kamuoyundaki makbuliyetini de Grek-Helen antik dünyasının torunları olma imtiyazı oluşturmuştur.

\section{Dönem Müşahit ve Neşriyatı Gözünden I. İnönü Savaşı}

Münferit askeri hareket tarzının temsili olan Kuvâ-yı Millîye, ismi ile müsemma bir hedefe kanalize olmaktan ziyade bölgesel hassasiyetlerle hareket ederek yerel bir hüviyeti temsil etmiştir (Özkaya, 1992, s. 457). Bu temsiliyet, İtilaf Kuvvetleri'nin parçalanmış Anadolu tasavvuruna ve bu uzlaşının küçük ortağı Yunanistan'ın Megali İdea tahayyülüne müsait bir ortam hazırlamıştır. M. Kemal (Atatürk) ve arkadaşlarının milli bir hissiyat ile münferit hareketleri müşterek bir hedefe koşullandırmak amacıyla kongrelerde ortaya koydukları çaba, Sivas Kongresi’nde düzenli bir ordunun kurulmasıyla sonuçlanmıştır. Söz konusu kongre kararı 16 Mayıs 1920 tarihli Büyük Millet Meclisi kararıyla teyid edilerek "Kuvâ-yı Millîye", "Müdafaa-i Millîye” teşkilatına 
bağlanmıştır. Bu tür bir gelişme, İtilaf Kuvvetleri'nin özelde ise İngiltere (Lloyd George şahsında) ve Yunanistan'ın (Venizelos şahsında) tasavvuratını ev tahayyülatını palazlandıran yerel direnişlerin sonu, mezkûr niyetlerin inkisar-1 hayale maruz bırakacak milli bir direnişin de başlangıcı olmuştur. Ancak bu geçişin sancıları Gediz Muharebesi'nde mağlubiyete neden olmuştur. Düzenli ordu içinde yerel alışkanlıkların neden olduğu bu başarısızlık, komuta merkezinde yapılan tayin/terfilerle ve cepheyi taksim/tasnifle tamir edilmek istenmiştir. Bu bağlamda Ali Fuat (Cebesoy) Moskova'ya elçi olarak tayin edilmiş, Batı Cephesi tasnif edilerek bir kısmını Garp Cephesi diğer bölümünü ise Cenup Cephesi oluşturmuştur (Öztoprak, 2000, s. 523). Garp Cephesine İsmet (İnönü) ve Cenup Cephesine Refet (Bele) tayin edilerek Gediz'de yaşanan hezimetin zaafiyetleri I. İnönü öncesinde bu tür önlemlerle telafi edilmeye çalışılmıştır.

Çerkez Ethem vak'ası mezkûr çabanın karşılaştığı son engellerden biridir. I. İnönü Savaşı'nın arifesinde ortaya çıkan nizami ordunun mizanına karşı bu serkeşlik hareketi seri bir şekilde tenkil edilmiştir. Ancak Çerkez Ethem'in sükûtu akabinde Yunanlılarla işbirliği yapması (Halıcı, 2016, s. 208-236) İnönü Savaşı'nın kapısını aralamıştır. Bu hüküm Millî Mücadele’nin sözcüsü Hâkimiyet-i Millîye tarafından ilk sayfada haber-yorum şeklinde sunulmuştur. "Yunanlılar Ethem'in teşviki ile ve onun ifşaatından istifade etmek isteyerek kuvvetli fırkalar ile Eskişehir üzerine yürüdüler. Hıyanetinden istifade eden düşman seri’ bir hareketle Eskişehir'e girerek mücadelenin Eskişehir etrafında dönen safhasını kazanmak istiyor ve Ethem'in pek tabi olan ifşaatına inanarak Eskişehir'e kolaylıkla girebileceğini de ümit ediyorlardı" (Hâkimiyet-i Millîye, 12 Kanun-1 Sani 1337, s. 1). Gazetenin aynı sayfasında M. Kemal (Atatürk)'in Büyük Millet Meclisi’ndeki konuşmasından da alıntılar yapılmış ve Ethem ihanetinin Yunanlıları cesaretlendirdiğine ilişkin haber-yorum teyit edilmiştir. Aynı gazetenin "müstahberat-ı mahsusamız" adlı bölümünde ise Ethem'in sadece Yunanlıların değil İngilizlerin de ümit kaynağı olduğu ifade edilmiştir (Hâkimiyet-i Millîye, 12 Kanun-1 Sani 1337, s. 1).

Ethem'in şahsi istikbal uğruna milletin istiklalini Anadolu'yu işgal edenlere pazarlaması, Garp Cephesi'nde askeri hareketliliği hızlandırmış ve I. İnönü ile başlayan savaşlar silsilesinin kapısını aralamıştır. Kısa vadede her iki tarafın büyük çaplı bir savaşa girişmesi, dönem müşahitleri tarafından pek gerçekçi görünmemiştir. Savaşın komutanı İsmet (İnönü) hatıralarında "Yunanlılar taarruz etmişler bizim mevzileri söktürmüşler ondan sonra hazırlıksız geldiklerini, gerisinin daha çok tehlikeli olduğunu anlayarak kendileri çekilip gitmişlerdir” (İnönü, 2009, s. 233) gözlemi yukarıdaki tespitin bir temsili görülebilir. Yunan ordularının taarruz kabiliyetinin dönem itibariyle sınırlı olduğu ve bahse konu devletin Anadolu’yu askeri olarak değil de sert diplomatik yöntemler, propaganda ve tedhiş siyasetiyle işgale niyetlendiği yine İsmet (İnönü) tarafından iddia edilmesi mezkûr tespitin teyidi mesabesindedir. "Yunan harbi zaten bir düşmanın muharebe ile işgal ettiği bir kıtanın üzerindeki muharebeler halinde olmadı. Yunanlılar Anadolu'ya muharebe ile akmadılar sulh yapmak isteyen bir memleketi istila etmek tarzında oldu ve bir yere kadar ilerledikten sonra kendi ihtiyaçları ile orada durdular Yunanistan'a bu yolu açan itilaf Devletleri de Yunanlılar da bir müddet beklemekte fayda umdular, umdular ki bu müddet esnasında iç isyanlarla çeşitli tertiplerle mesele kendiliğinden hal olacaktır. Bu politikayı takip ettiler" (İnönü, 2009, s. 230).

I. İnönü Savaşı'nın sonuçları üzerinden yapılan yorumlardan biri de Ali İhsan Sabis tarafından dile getirilmiştir. Konuya ilişkin gözlem ve görüşlerini Kılıç Ali’ye isnat ederek yaptı̆̆ 1 tespit de hem Yunan Kuvvetleri'nin hem de Türk Kuvvetleri'nin böyle bir savaşı yürütecek bir hazırlığının bulunmadığı yönündedir. Çünkü taarruz halinde olanların ricat üzere hareket edenlerin hamlesine karşıllık veremeyip aksine geri çekilmelerini dolaylı olarak “dostlar çarşıda görsün” türünden bir askeri hareket olarak tasvir etmiş, diğer taraftan Türk Ordusu'nun da böyle hazırlıksız bir taarruz karşısında mukavemet edemeyişini komuta merkezinin kabiliyetsizliği üzerinden anlamlandırmıştır. Yunan ordusunun taarruza elverişli bir yapıda olmadığ , Türk Ordusu'nun ise komuta ve koordinasyondan mahrum olması mücadelenin ana karakteri olarak vasıflandırılmıştır (Sabis, 1993, s. 334). Sabis'in bakış açısı dikkate alınarak Yunan taarruzuna ilişkin yapılan 
bu tavsif, dönem İstanbul neşriyatı tarafından da dile getirilmiştir. Atina ve Avrupa merkezli gazetelerin haberyorum sayfalarını referans alarak neşrettikleri haberlerde, Yunan Kuvvetleri'nin zikredilen taarruza teşebbüs nedenini Yunanistan'daki siyasi, iktisadi ve sosyal çalkantıların üstünü örtmek, Londra ve diğer Avrupa merkezlerine mesaj vermekten kaynaklandığı öne sürülmüştür. Çünkü bu taarruz Sevr muahedesine rağmen gerçekleştirilmiştir. Yunanistan'ın ileri harekete geçerek Eskişehir hattındaki taarruz teşebbüsünün en makul açıklaması, Paris Konferansı öncesinde hem kendi pozisyonunu pekiştirmek hem de jandarmalığına soyunduğu İtilaf kuvvetlerinin İstanbul karşısında elini güçlendirmek olduğudur. Dönem diliyle ifade edilirse "siyasiyat aleminde nazar-1 dikkate alınacak şey ekvalden ziyade ef 'aldir." (Vakit, 12 Kanun-1 Sani 1337, s. 1). İstanbul neşriyatı tarafından dile getirilen iddiaların tarihi bir temeli de mevcuttur. Bu temel, I. Dünya Savaşı'nın öncesinde başlayan Venizelos ve Konstantin arasındaki siyasi mücadelenin 1921'deki kazananının Konstantin olmasında sonra Venizelos taraftarlarının kazan kaldırmasından ve İngiltere nezdinde Avrupa'nın jandarmalığını yürüteceğine ilişkin mesaj verme endişelerinden kaynaklanmaktadır. Avrupa'da yayınlanan gazetelerden yapılan alıntılarla yapılan haber-yorumlarda "Şu halde Rallis kabinesi Yunan İ'tilaf devletlerine karşı Yunan ordusunun hiç olmazsa hal-i inhilalde olmadığını göstermeğe gayret etmek mecburiyetini his eylemektedir."

İşte bizim anladığımıza göre Bursa ve Uşak cephelerinde başlayan yeni taarruzun hedef-i siyasiyesi bundan ibaret. Konstantin hükümeti bu hareket ile İtilaf Devletleri'ne bizim Anadolu hakkındaki verdiğimiz teminatı yalnız sözde bırakmayacağız. Bu teminatı fiilen yerine getireceğiz işte, işte başlıyoruz. Yalnız Paris Konferansı'ndan istirhamımız şudur; Venizelos hakkında gösterilen muaveneti Konstantin hükümetinden de diriğ etmemeniz, demek istiyor ve bir kere bu muvaffakiyet-i siyasiyeyi elde ettikten sonra Venizelosculara karşı vaziyeti tahkim edeceğini tahmin ediyor.” (Vakit, 12 Kanun-1 Sani 1337, s.1).

I. Dünya savaşında İtilaf Kuvvetleri tarafında savaşa girmeme arzu ve iştiyakıyla Venizelosçulara karşı mücadele eden ve savaş sonrasında Anadolu'nun işgaline karşı muhalefet eden Konstantin'in, selefinin politikalarının bir halefi olarak hareket etmesi diğer bir ifadeyle Anadolu'daki yayılmacı politikayı sürdürmesinin altında yatan etkenler, siyasi ve iktisadi buhranlarına askeri muvaffakiyetlerle çözüm üreterek İngiltere'nin muavenetine nail olmak kaygısından ileri gelmiştir (Hâkimiyet-i Millîye, 10 Kanun-1 Sani 1337, s. 1). Konu ile ilgili Mustafa Kemal (Atatürk)'ün Mecliste gündeme ilişkin yaptığı konuşmada aynı vurgular söz konusu olmuştur. Mustafa Kemal (Atatürk), “Yunanistan'da Venizelos'un sükûtu ile Kral Konstantin'in avdeti meseleleri vaziyet-i siyasiyede büyük bir burhan eylemiş idi. Kral Konstantin'in takip edeceği siyasiyat ilk günlerde tamamen anlaşılamamış idi. Mamafih, İngiliz emperyalist emellerini tahsil edebilmek için Kral Konstantini de tatbik ederek maksatlarında istihdam eğlenmeye çalışıyorlardı. Kostantin de krallığını tekrar ele geçirebilmek için buna mütemayil görünüyordu.” (Hâkimiyet Millîye, 15 Kanun-1 Sani 1337, s. 1).

Konstantin, iç ve dış siyasette kendi meşruiyetine ilişkin endişeleri ekarte edebilmek için "imparator" edasıyla Venizelos'un bile yapamadığı bir niyeti hayata geçirmek istemiş ve İzmir cephesine gitmeye karar vermiş ve bu niyet, Vakit gazetesinin haber-yorum kısmında şu şekilde tasvir edilmiştir. "Cephe ziyaretinin Avrupa'da şaşalı akisler vücuda getirebilmesi için aynı zamanda bir hareket askeriye yapılmasını tensib eylemişti. Konstantin ile hükümeti tarafından tensib edilen bu hareket Eskişehir'e doğru vuku bulan taarruzdan ibaret idi. Bir taraftan Kral Konstantin'in Asya-yı sugra cephesine gideceği Londra gibi Avrupa merkezi siyasiyesinde resmen ilan edildi diğer taraftan Burusa cihetinden Eskişehir'e doğru Yunan kuvvetlerine ileri emri verildi ve hatta ilk günlerde muvaffakiyetler bile elde edildi ve bu muvaffakiyetler tebliğ-i resimler ile bütün cihana bildirildi. Artık Kral Konstantin'in İzmir'e azimet ederek ihraz edilen zaferlerin iklil-i şerefini hame i gururuna vaz etmesi kalıyordu. Hatta İzmir'de Konstantin'in ikametine mahsus olmak üzere bir şato bile ihzar edilmişti.” 
I. İnönü Savaşı bu tür hesaplarla Yunanistan tarafından başlatılmıştır. Kendi iç kamuoyunu konsolide edebilmek ve İngiltere önderliğindeki Avrupa'nın muavenetine muhatap olabilmek amacıyla alelacele başlatılan taarruza ilişkin ilk haberler 10 Kanun-1 Sani'de (Ocak) gazetelere yansımıştır. Yunan Karargah-1 Umumi'sinin 8 Kanun-1 Sani (Ocak) resmi tebliğinde Bursa Cephesi’ndeki Yunan kitalarının 6 Ocak itibariyle İnegöl'ün doğusunda kuvvetli surette mevzi tutmuş olan Türk Kuvvetleriyle (resmi tebliğde Kemal Kuvvetleri olarak tesmiye edilmiştir) çarpışmışlar, bunları mağlup etmişler ve Nazif Paşa'nın -mevkii- ötesine kadar takip etmişlerdir. Yunan askeri kaynaklarına göre taarruzun ilk aşamasında 3 mitralyöz 3'ü küçük zabit ve 1'i binbaş1 olmak üzere 50 esir ele geçirilmiş ve bir miktar yük hayvanı (mevaşi) ile yürüyüşlerine devam etmişlerdir. Garb Cephesi'nde olduğu gibi Cenubi Cephesi'nde de Türk kuvvetlerinin ricati söz konusu olmuştur (Vakit, 10 Kanun-1 Sani 1337, s. 1).

Zikredilen tarih ve çarpışma ile ilgi Hâkimiyet-i Millîye gazetesinin resm-i tebliğ bölümünde 7 Kanun-1 Sani 1337 başlı̆̆ı altında sırayla cephelerdeki gelişmeleri paylaşılmış ve 1'nolu tasnifin karşısına Garp Cephesi'ndeki duruma ilişkin "henüz malumat alınmamıştır" notu düşülmüş̧ür. (Hâkimiyet-i Millîye, 8 Kanun-1 Sani 1337, s. 2). Ancak savaşın kumandanı İsmet (İnönü) hatıralarında, belirtilen tarihlerde Yunan ordusunun Bursa bölgesinden üç kol halinde ilerleyerek karşısında zayıf kuvvetlerin mukavemetini kırıp İnönü mevzilerine ulaştıklarını ifade etmiştir (İnönü, 2009, s. 231). Hâkimiyet-i Millîye’nin bu tarihteki suskunluğunun muhtemel nedenlerinden birisi, cephedeki zaafiyetlerin kamusallaştırılmasıyla hem siyasi, askeri hem de içtimai zihinlerde oluşturulmakta olan birliğin geleceğine ilişkin korkudur.

Hâkimiyet-i Millîye gazetesinin kamusallaştırmaktan çekindiği geri çekilme haberleri, 9 Ocak tarihli Yunan tebliğ-i resmisini kaynak alan Vakit gazetesi tarafından okurlar ile paylaşılmaya devam edilmiştir. Gazete haberinde Yunan kıtalarının ileri hareketle Pazarcık tepelerinde Türk Kuvvetleriyle müsademeye devamla, Türklerin Eskişehir'e doğru firar ettiği bildirilmiştir. 150 esir ve henüz ta'dat edilemeyecek birçok mühimmat elde edildiği ve Bağdat şimendifer hattının Karaköy şimendifer istasyonu, saat 14'te ele geçirildiğine yönelik Yunan askeri kaynaklarının gözlemleri paylaşılmıştır. Bu süreçte Yunan kayıplarının 3 ü maktul 5 mecruh olarak toplam 8 kişi olarak tespit edildiği ancak Yunanlılar tarafından bu rakamların elde edilen muvaffakiyetler karşısında kayda değer olmadığı görülmüştür (Vakit, 10 Kanun-1 Sani 1337, s. 1).

İsmet (İnönü) bu tarihe ilişkin notlarında ise genel bir değerlendirme yaparak kendisinin 9 Ocak itibariyle İnönü mevkiine yetiştiğini ve muharebelerin devam ettiğini, Türk kuvvetlerinin mukavemet etmeye çalıştığını ancak İnönü İstasyonu’nun işgal edildiğini hatıralarında dile getirmiştir. Fakat kendisiyle birlikte gelen kıtalar sayesinde istasyonun istirdadının sağlandığını, 9-10 Ocak günlerinde şiddetli çarpışmaların olduğunu ve ortaya çıkan tabloyu ise "alıyoruz, veriyoruz, geliyorlar, yetişiyoruz, taarruz yapıyorlar biz mukabelede bulunuyoruz" şeklinde tasvir etmiştir (İnönü, 2009, s. 231-32).

Yunan askeri kaynaklarının I. İnönü Savaşı'nın "son” aşamasına ilişkin "son” resm-i tebliği 13 Ocak tarihli İkdam gazetesi tarafından okurlarına sunulmuştur. Gazete, "Eskişehir civarında büyük bir muharebe" başlığıyla kamuoyuna servis ettiği cephe haberlerinde belirtilen tarihten iki gün önce vuku' bulan çatışmaların harbin en şiddetli günü olduğunu ve bu durumu da teyit makamında sayısal verilerle sergilemiştir. Ankara hükümetinin yüzlerce ölü verdiği ve bir tayyaresinin tahrib edildiği muharebede Yunan ordusunun ise 9 zabitan ve 30 neferinin maktul, 8 zabitan ve 159 neferinin de mecruh olduğu ifade edilmiştir. (İkdam, 13 Kanun-1 Sani, 1921, s. 1).

İstanbul neşriyatının Yunan taarruzlarına ilişkin paylaştıkları son haber 11 Ocak’ta vuku' bulan ve 13 Ocak'ta yayınlanan Yunan tebliğ-i resmisidir. Bu tarihten sonra taarruza ilişkin haberler Hâkimiyet-i Millîye tarafından servis edilmeye devam edilmiştir. 11 Ocak tarihli Yunan taarruzunun akamete uğratılarak geri 
püskürtüldügüne ilişkin haberlerde 10 Kanun-1 Sani 37 gününde Yunanlıların devam eden şiddetli taarruzlarının Türklerin cansiperane müdafaa ve mukavemetleriyle ve mukabil taarruzlarıyla kırılarak tevkif (durdurulduğu) eylendiği bildirilmiştir. Düşmanın yeni kuvvetler celp ile taarruzlarına devam eylemesi sebebiyle kuvvetlerimizin Söğüt ve Bozüyük cenubundaki mevazi-i müstahzaraya çekildiği yeni mevazi’ imizin sol cenahındaki Kovalıca hattı müdafaamıza iki koldan ilerleyerek taarruz eden düşmanın, kıt'amızın dilirane mukavemeti karşısında şedid bir muharebeden sonra tevakkufa mecbur olduğu okurlara duyurulmuştur. Kanun-1 Sani'nin 11. Salı günü de düşman meydan harbinde peki külliyetli zayiat vererek ricata başladığının müjdesi paylaşılmıştır. Savaşın şiddeti noktasında her iki tarafın belirtilen tarih aralığına ilişkin vermiş oldukları haberlerin uyuştuğu ancak hezimet noktasındaki iddialar için aynı yorumları yapmak mümkün değildir. Hâkimiyet-i Millîye, ordumuz takibata başlamıştır. Efrat ve zabitan ve kumandanlarımızın fedakârlıklarını azim minnettarlıklarla takdis ve tebrik eyleriz (Hâkimiyet-i Millîye, 12 Kanun-1 Sani 37, s. 2) haberi, muzaffer tarafın kim olduğunu ilan ederken Yunan askeri kaynaklarına ev sahipliği yapan İstanbul neşriyatının sessizliği de mağlup tarafın kim olduğuna ilişkin bir kanaati ortaya çıkarmıştır.

$\mathrm{Bu}$ tarihten sonra Yunan makamları taarruzla ilgili bir bildirimde bulunmak yerine taarruzlarının akamete uğratılmasını sivil insanların zarar görmemelerini önemsediklerinden kaynaklandığını ifade etmişlerdir. Ancak aynı iddialar yine Hâkimiyet-i Millîye tarafından yalanlanmış 14 Kanun-1 Sani 1337 tarihli tebliği okurlarıyla paylaşarak Garp Cephesi'nde düşmanın birçok eşya ve malzemeyi terk ederek Yenişehir ve İnegöl istikametinde süratle ve perişan bir halde ricata devam ettiğini Söğüt ve Pazarcık’’ tahliye eden düşmanın ricat esnasında birçok köy ahalisini katl ve kadınlara tasallut ettiklerini bildirmiştir (Hâkimiyet-i Millîye, 15 Kanun1 Sani 1337, s. 2). İstanbul neşriyatı ise Yunan resm-i tebliğini, başarısızlıkların maskesi olarak değerlendirip İstanbul ve Avrupa'ya yönelik yapılmış bir imaj çalışması olarak görmüştür. İlgili haber Vakit gazetesinde şu satırlarla tasvir edilmiştir. "Dünkü nüshamızda münderiç Yunan tebliğ-i resmileri Bursa havalisinde başlayan son Yunan taarruzunun Eskişehir civarında tevkif edildiğini bildiriyordu. Yunanlılar bu tevkife sebep olarak birçok nüfusa muhtevi bulunan şehrin harabeye uğraması ihtimalini mevzu bahsediyorlardı. Bursa gibi Eskişehir'den daha büyük ve daha çok nüfusu muhtevi mahalleleri işgal etmekten çekinmeye ve ne derece insaniyet pervane hisler ile hareket ettiği şimdi tamamıyla tezahür etmiş bulunan Yunanlıların Eskişehir havalisinde münhasıran bu gibi insanı düşüncelerle tevkif ettiğine inanmak bir parça fazla safdillik olur. Hakikat şudur ki Yunan kuvvetleri ilk muvaffakiyetler i müteakip şiddetli bir mukavemete müsadif olmuş ve bu mukavemet neticesinde taarruz hareketini tevkif etmeye mecbur kalmıştır.” (Vakit, 14 Kanun-ı Sani 1337, s. 1).

Konstantin'in meşruiyetine koşullandırılmış olan bu askeri hareket, muhasiplerin (Yunanistan) hesaplarına değil de Millî Mücadelenin birlik ve beraberliğine hizmet etmiştir. İsmet (İnönü) Yunan Kuvvetleri karşısında elde edilen muvaffakiyetin, Anadolu'nun teveccühüne temel olarak var olan sıkıntıların aşılmasında önemli bir eşik olduğunu hatta İstanbul'un takdirine dahi ortam hazırladığına değinmiştir (İnönü, 2009, s. 233-236). Mustafa Kemal (Atatürk)'ün görüşünü referans alarak I. İnönü Savaşı’nın sonucu itibariyle nasıl bir siyasi geleceğe hizmet ettiği İsmet (İnönü) tarafından şu şekilde tavzih edilmiştir. "Mustafa Kemal Paşa çok memnun olmuştu. Beni istasyonda karşıladı. Kendisine "Büyük mesele halledildi” dedim. "Hangi büyük mesele? Çok, çok mesele hal olundu" diye cevap verdi. O kadar memnun görünüyordu ki... Hükümet henüz kuruluyordu. Dağınık hükümetten kurtulmak, ordu teşekkül edecek mi, etmeyecek mi endişelerinden sıyrılmak ve ilerisi ne olacak gibi şüphe ve tereddütler içinde bulunulan bir atmosferden birdenbire siyrllarak normal bir harbin tertiplerine, fevkine ve manevi kuvvetlerine girmiş olduğumuz bir devredeydik. Ankara'da, 23 Nisan 1920'de Meclisin açılmasından Birinci İnönü Muharebesi'nin sonuna kadarki zaman, büyük buhranlarla geçmişti. Herkes milli hareketin iç isyanlarla çöküp batacağını ve davanın esasından temelli kaybolacağını beklerken, şimdi muharebe ile bir netice almak zihniyeti, şevki hasıl olmuştu. Birinci İnönü Muharebesi umumi itibarı kuvvetlendirir mahiyette bir netice sağlamış oldu." (İnönü, 2009, s. 233-234). 
İsmet (İnönü), Yunan taarruzları karşısında elde edilen bu muvaffakiyetin sadece siyasi bir geleceği inşa etmediği aynı zamanda vatanı kendi mahalli değerleri ile bir tutan anlayışın tutarsızlıklarını ifşa ve afişe ederek artık parçaya değil de bütüne (vatana) odaklanan bir zihniyeti doğurduğunu ifade etmiştir. "Birinci İnönü Muharebesi ve Ethem'in tasfiyesi gerçekten çok meseleyi halletmişti. Şimdi bu meseleden birini söyleyeceğim. Bizim orduda bugünlere kadar büyük bir hastalık vardı. Yedi-sekiz aydan beri asker alırız, getiririz, giydiririz, besleriz, fakat silahını almış, cephanesini beline takmış, firar edip giderdi. Firarileri evine kadar takip ederiz, imkânı yok tutamayız, iş manevi bağlılığa kalmıştı. Aramızda görüşüyoruz, çare arıyoruz. Nihayet karar verdik ki, firarı önlemek için manevi kuvvet ve bağlılık tesis etmek lazımdır. Buna çalışalım dedim. Ancak, manevi kuvvetin, vazife hissinin teessüs etmesi ve firarların önlenmesi için ilk manevi çare bir muvaffakiyet göstermektir, inanıyoruz, biz muvaffak olabiliriz, muharebe kazanabiliriz. Daha doğrusu bunun için muharebe kazanmak lazımdır. Buna karşılık içinde bulunduğumuz güç şartlar içinde umumi şevki yükseltmek ve bir zafer kazanmak için de iyi bir kıta teşkil etmek lazımdır. Muzafferiyet kazanırsak, iyi kıta teşkil etmenin yoluna girmiş olacă̆ız. Ama muzafferiyeti kazanmak için de elde iyi kıtaların bulunmasına ihtiyaç vardı. Böyle bir muammayı halletmeye çalışıyorduk. İşte Birinci İnönü Muharebesi ile bu muammanın hallinde esaslı bir adım atmış olduk." (İnönü, 2009, s. 234).

\section{Sonuç}

Savaş tarihine ilişkin kaleme alınan eserlerde cephe gerisinin en az cephe kadar önemli bir yer tuttuğu bilinmektedir. Bu umum kaideyi “mevziinin kuvveti, mevkiinin kudretinden ileri gelir” fikri sabitiyle teyid edilirse, mevziinin temsilini cephe, mevkiinin temsiliyetini ise millet teşkil etmiştir. Bir tarafta Mustafa Kemal (Atatürk) ve silah arkadaşlarının Anadolu'daki mücadelenin müteharrik güçlerini (cemiyetler) meclisin şahsında bir ve beraber kılma çabaları, diğer tarafta Kral Konstantin ve taraftarlarının yine aynı coğrafyadaki Venizelosçu ve Kralcı şeklinde ayrışmış ordusunu Megali İdea tahayyülünde birleştirme gayretleri bir önceki cümlede bahse konu önermenin tatbikatlarıdır. Bu uygulamaların reaksiyoner veçhesini askeri mukavemet, aksiyoner cihetini ise içtimai muavenet ve teavün oluşturmuştur. Reaksiyoner ve aksiyoner taraflar arasında bir ahenk tesis ederek bir ve diri olmanın vasıtasını ise kitle iletişim araçları üstlenmiştir.

Anadolu'nun istiklal ve istikbaline koşuşturanlar ile bu coğrafya üzerinde "Megali İdea" idealine koşullandıranlar arasındaki savaşların ilk aşaması, her ne kadar Batı Anadolu'da vuku' bulmuş çarpışmalar olsa da İsmet (İnönü)'nün de ifade ettiği üzere Millî Mücadele’nin gerçek askeri safhası I. İnönü Savaşı ile başlamıştır. Savaşın kalibresini, her iki tarafın çarpışma öncesinde kendi iç siyasetinde yaşadıkları çekişmeler belirlemiştir. Bu tabloyu şu şekilde tasnif ve tarif etmek mümkündür:

- Millî Mücadeleciler, nizami ordunun intizamına yönelik başkaldırıları tenkil, hilafet ve saltanat yanlısı isyanları te'dib ve iktisadi sorunlarını telafi etmenin yorgunluğuna rağmen "İnönü" de kendini müdafaa zorunluluğu...

- "Müstevli" konumundaki Yunanistan da ise Kral Konstantin ile Venizelosçular arasında yaşanan siyasi kargaşanın, toplumsal ayrışmalara, askeri darbelere ve iktisadi buhranlara sebebiyet vermesinin meydana getirdiği tükenmişlik duygusuna rağmen taarruza kalkışması...

Böyle bir tablo I. İnönü Savaşı'nın şiddetinin sonraki muharebelerle mukayese edildiği zaman küçük çaplı bir çarpışma olarak nitelenmesine, elde edilen galibiyetin de İsmet (İnönü) tarafından "mütevazı ölçüde bir zafer" olarak değerlendirilmesine yol açmıştır. 
I. İnönü Savaşı'nın cephe gerisinde yaşanan sıkıntıların giderilmesinden önce vuku' bulması, savaşın ölçeğini belirlediği gibi muharebenin yürütülmesinde de her iki tarafın belli zaafiyetelerle yüzleşmesine neden olmuştur. Bu eksikliklerin üstü ise kitle iletişim araçları ile örtülmeye çalışılmıştır. Yunan taarruzunun ilk aşaması Hâkimiyet-i Millîye gazetesi tarafından göz ardı edilmesi Millî Mücadele tarafının bu süreçte mukavemet edemeyip geri çekilmesinden kaynaklanmış, savaşın son safhasında Yunanlıların ricatı ise Yunanistan resmi kaynaklarınca insani kaygıları öne sürülerek çarpıtılmıştır.

Savaşan taraflar açısından bahse konu eksikliklerin kitle iletişim araçları tarafından üstü örtülerek cephe gerisine servis edilmesinin iki amaca matuf olduğu, metin içerisinde vurgulanmıştır. Savaşa koşullandırılmış Konstantin için hem Avrupa'ya iletilecek yeni imajın oluşturulması hem de kendi iç kamuoyuna verilmesi beklenen mesajın adrese ulaşması söz konusu olmamıştır. Konstantin'in şahsında bu savaş "Dimyata giderken evde ki pirinçten olmak” şeklinde sonuçlanmıştır. Harbe koşuşturanlar olarak tesmiye edilen Millî Mücadele taraftarları açısından ise bu savaş yeni bir ilişki biçimi ve inanç ortaya çıkarmıştır. İnanç istiklale, yeni ilişki biçimi ise istikbalin siyasi söylemine ilişkindir. Mustafa Kemal Atatürk'ün savaş sonrasında "millet ve memleket nam ve hesabına yegâne müracaatgâh burasıdır, yani Meclis-i Âlinizdir. Bu hakk-ı meşrui, bu hakk'1 millîyi, bu hakk-1 tabiîyi hiçbir sebep ve bahane ile hiçbir mütalaa ile hiçbir şahsa ve hiçbir hey’ete terk edemeyiz." (Şeref, 2011, s. 97) sözleri mezkûr ilişki biçiminin istinatgâhının artık İstanbul değil Ankara olacağının işaretidir.

\section{Kaynakça}

Atatürk, M. K. (1969). Nutuk. C.II, İstanbul: Milli Eğitim Basımevi.

Cebesoy, F. A. (2019). Millî mücadele hatıraları. İstanbul: Temel Yayınları.

Celal Nuri (29 Ağustos 1335). Hikmet-i hükümet-i osmaniye. İleri, s.1.

Çetin, İ. (2018). Osmanlı kaynaklarına göre Yunanistan'ın I. Dünya Savaşı'na girişi. Karam, 59(XV), 169-204. https://doi.org/10.12787/KARAM1348

Edhem Veysi, (25 Şaban 1340). Ne gündeyiz. Hayat. s.1.

Erdem, N. (2009). Yunan tarihçiliğinin gözüyle Anadolu Harekâtı (1919-192). (Yayımlanmamış Doktora Tezi). İstanbul Üniversitesi Sosyal Bilimler Enstitüsü, İstanbul.

Hâkimiyet-i Millîye, (8 Kanun-1 Sani, 1337)

Halıcı, Ş. (2016). Ethem. İstanbul: e Yayınları.

Hâkimiyet-i Millîye, (8 Kanun-1 Sani 1337)

Hâkimiyet-i Millîye, (12 Kanun-1 Sani 1337)

Hâkimiyet Millîye, (15 Kanun-1 Sani 1337)

Hilal, (23 Nisan 1922.)

İkdam, (13 Kanun-1 Sani, 1921)

İkdam, (14 Kanun-1 Sani 1921)

İnönü, İ. (2009). İsmet İnönü hatıralar (Sabahattin Selek, Haz.). Ankara: Bilgi Yayınları.

İrade-i Millîye, (1 Mart 1336.)

Karaosmanoğlu, Y. K. (1973). Ergenekon (Millî mücadele yazllarl). İstanbul: Remzi Kitabevi. 
Küçük, C. (2009). Sevr Antlaşması. DİA, Cilt 37 (s. 1-5). İstanbul: Türkiye Diyanet Vakfı.

Özkaya, Y. (1992). Kuvâ-y1 Millîye, Atatürk Araştırma Merkezi Dergisi, 24(8), 451-480. https://dergipark.org.tr/tr/pub/aamd/issue/55244/757961.

Öztoprak, İ. (2000). Birinci İnönü Savaşı'nın Anadolu, İstanbul ve dış basında karşılanışı ve yorumu. Belleten. 240(LXIV). 523-540. https://dergipark.org.tr/tr/pub/ttkbelleten/issue/602

Sabis, İhsan A. (1993). Harp hatıralarım İstiklâl Harbi ve gizli cihetleri. C.5. İstanbul: Nehir Yayınları.

Sağlamer, K. (1971). Anadolu'nun işgali ve Yunan mezalimi hakkında müttefiklerarası komisyonun raporu, BTTD, 9(40) 5-10.

Şeref, M. (2011). Birinci Millet Meclisi (tarihi ve siyasi tefrika). T. Lüleci, (Haz.). İstanbul: Yeditepe Yayınları.

Vakit, (10 Kanun-1 Sani 1921)

Vakit, (12 Kanun-1 Sani 1337)

Vakit, (14 Kanun-1 Sani 1337)

Vatan, (9 Kanun-1 Sani 1921)

TBMM. ZC., (9 Kanun-1 Evvel 1336)

TBMM. GZC., (8 Kanun-1 Sani 1337)

TBMM. GZC., (17 Mart 1337)

\section{Extended Abstract}

\section{Purpose}

In the study, it was questioned what is the purpose of the war between the Turkish and Greek military units started in January 1921 and what has Greece expected from the war? In addition, the study explores how the gains of the war shape their moment and tomorrow from the point of view of the Turks who defend themselves. On the other hand, the duration of the war and the nature of the operation were showen why it was a smallerscale battle by including the factors that caused this situation. How both sides tried to use the mass media efficiently to hide these factors caused by their internal contradictions is among the goals of the study.

\section{Design and Methodology}

Political, economic, military and social maps of Greece before the war were drawn through the newspapers in the period of King Constantine, who had different expectations without taking into account the necessary material and spiritual means for the continuation of the war. This function was carried out through newspapers published in Istanbul. The fact that these newspapers translate news sources on the situation of Greece to newspapers published in various European capitals, especially in Athens, made it easier for us to work. Likewise, the process that defenders are exposed to and the traumas this process has created in the political, military, economic and social spheres are also told through the newspapers and witnesses of the period. Comparing the shortcomings of both sides before the war with this method, the table that appeared during the war was presented to the reader by the same method. By comparing the deficiencies of both sides before the war with this method, the picture that emerged during the war was presented to the reader with the same method. For this reason, primary sources were used in a similar way in the proposed study. 


\section{Findings}

The internal contradictions of both sides fighting over the sources and methods mentioned in the upper paragraph were explained, and how such a picture affected the war process and the outcome of the war was determined. The difficulties experienced by both sides before the war directly affected the severity, nature and expectations of the war. Greece has had two expectations from this war. These were to eliminate the economic cost of the political struggle between Venizelos and Constantine, the polarization caused by the social sphere, the conflict in the military sphere, and to consolidate the internal public opinion with the invasion of Anatolia, which he established on nationalist and historical discourses, and to get the help of Europe. The decomposition caused by the stated internal contradictions began to occupy public opinion loudly.

This disappointment of Greece, which started the war with great expectations, led to a new light of hope in Anatolia, which resisted the occupation. The pre-war situation of the Turks, who defend their independence and their future, and these shortcomings explained through the sources mentioned, became a motivation tool rather than creating a disadvantage for the army. The greatest Spoils of the Battles of Inönü were the elimination of concerns and fears about independence and the future. The Battles of İnönü revealed a consciousness that would define the homeland as a geography on which the unity of language, religion, history and culture is located, rather than an understanding that views the land with its own committed and inhabited land. This war has instilled in the Turkish nation a consciousness that will not abandon its own fate to the protection of a foreign state or the initiative of Istanbul, and has been a harbinger of an understanding that will bring Ankara to the forefront as the founder of its future.

\section{Research Limitations}

As for the results of the First Battle of İnönü, while it was considered as a disappointment for Athens and it was considered as a success that was not in the account from the point of view of Ankara. But this assessment does not point to a set of realities that both sides agree on. The fact that wars are not only about fighting with weapons in the field, but also about propanganda with a pen on the table, the problems in the reliability of the news and information transmitted by the period observations reflected in the newspapers are highlighted as the limitations of the research.

\section{Implications}

Periods when historical events were mixed and interpreted with ideological obsessions are the years of the establishment of states. One of the countries where these comments were most concentrated in order to condition the legitimacy of their existence were the parties to the Battles of İnönü. The propaganda war of both sides regarding the Battle of Inönü, which was the first step in the development of the establishment of Turkey and the unrealistic historical dream of Greece, has been the most important problem of such research. The method of interpreting historical events more reliably in such a picture is to take into account the spirit of time, the potential of space, and the characteristics of the subjects operating in both objectivities. Taking into account the impossibility of projecting the past into a mirror, it is possible that his picture close to the truth will be drawn in this way.

\section{Originality/ Value}

The internal contradictions and expectations of those who participated in the Battles of İnönü were evaluated within the possibilities of the time and space in which they were located and their impact on the violence and consequences of the war was investigated. This method has shown that the claims made about the Battles of İnönü are not facts, but historical rumors based on their political preferences.

Araştırmacı Katkısı: Ercüment TOPUZ (\%100). 